2017-01-02

\title{
The hotel in history: evolving
}

\section{perspectives}

\author{
James, KJ
}

http://hdl.handle.net/10026.1/12312

10.1080/1755182x.2017.1343784

Journal of Tourism History

Informa UK Limited

All content in PEARL is protected by copyright law. Author manuscripts are made available in accordance with publisher policies. Please cite only the published version using the details provided on the item record or document. In the absence of an open licence (e.g. Creative Commons), permissions for further reuse of content should be sought from the publisher or author. 


\title{
The Hotel in History: Evolving Perspectives
}

\author{
Professor Kevin James:
}

The contributors to this panel on hotel history focus on the hotel's complex position not only within infrastructures of travel, but also within codes and practices of hospitality, and economic and technological systems. All are distinguished scholars of the hotel, approaching it in a variety of contexts, and with different concerns imperialism and colonialism; science technology; its transatlantic form; its distinctive role in American cultural, social and commercial development. What unites the reflections that follow is a concern for the hotel that treats it not only within the framework of travel and tourism history, but within wider arcs of modernity, urbanism, and capitalism. This does not mean that these scholars subscribe to the same interpretation of the hotel's development - or indeed to the same precise definition of a 'hotel', yet alone to the same theoretical apparatus; but their insights underscore the fruitful ways that the hotel can be engaged as an historical subject - as a space that shapes the contours of sociability, capitalism, and relations of class, gender and race. Given scope as wide as their word limit was narrow to reflect on the current state of hotel history, these contributors offer thoughtful reflections on what recent hotel history has contributed, and what does it have the potential to contribute, to the study of hospitality, travel, industrialisation, politics and sociability.

We begin with the reflections of A.K. Sandoval-Strausz, whose award-winning book Hotel: An American History set a new agenda for exploring the distinctive American incarnation of the commercial hostelry. His reflections on an agenda for hotel history are followed by those of the eminent scholar Daniel Maudlin who, adopting a transatlantic perspective, queries the distinctiveness of the institutional categories of 'hotel' and 'inn', and seeks to clarify not only this nomenclature but also to critically interrogate the 'birth' of the hotel as a durable, fixed idea. These reflections are followed by a contribution by Maurizio Peleggi, known for his influential model for exploring the hotel both as a 'contact' and as 'comfort' zone, and its relationships to colonial modernity. He offers reflections on the forms and functions of the colonial hotel which at once extended the influence of, and distinguished it from, the métropole. Cédric Humair, a scholar of one of Europe's preeminent sites of hotel development, Switzerland, emphasises the vibrancy of scholarship on the subject in continental Europe, especially relating to the centrality of the hotel as a business - a subject he has studied extensively, and signals the extent to which the political frameworks within which individual hotel and districts developed, and through which interests such as hoteliers organised, are central to the historiography of the hotel. Finally, Molly Berger offers some timely reflections on how the study of the hotel, which in her case has been especially concerned with the relationship between technology and narratives of progress and modernity in America, hold valuable lessons for how we conceive of branding, technology, and 'hotel personality' today.

\section{Professor Andrew K. Sandoval-Strausz:}

It has been nearly a century since sociologists, urbanists, and various theorists first became interested in hotels. They saw hotels as manifestations of the broader social 
and economic processes that had engendered their fields of inquiry in the first placethe growth of cities, the industrialization of production, and the growth of complex business forms and state bureaucracies. In other words, hotels were sites of modernization and modernity - the dominant concepts that they elaborated to help understand the dramatic changes their world was undergoing. Thinkers like Robert Park and Louis Wirth used the hotel as an example of or metaphor for some of the classic conditions of modernity: transience, anomie, gesellschaft, et cetera. It made sense that the rise of the hotel as an institution epitomized the inevitable rise of the modern era. But this use of hotels was more of a theoretical persuasion than an empirical inquiry.

One of the roles of historians has been to query and question and sometimes dismantle the grand narratives that have emerged from other fields, using the evidence of past human experience and endeavour to evaluate theoretical claims. And modernization has been one of the narratives that historians and other scholars have called into question. As we have looked more closely at hotels and similar forms of commercial hospitality, we have discovered all kinds of unevenness, contingency, and contestedness that challenge the earlier theoretical portrait of hotels as the vanguard of modernization. Our histories have been less about zeitgeist and more about experimentation, contingency, and conflict.

We might begin with the discontinuities in the development of hotels and hospitality, whether over time or across space. My own hotel history began by problematizing the abrupt appearance of hotels in the United States of the 1790s after nearly two centuries during which the colonists of British North America made do with fairly rudimentary taverns. The development of commercial hospitality, I sought to show, was not simply a story of methodical and orderly improvement, but a contingent process that had everything to do with political manoeuvring, national identity, and personal ambition. By the same token, I found very different developmental trajectories even in places with similar cultures and structures of governance. For example, from a shared jurisprudence in the eighteenth century, the Anglo-American laws governing hospitality diverged dramatically in the nineteenth century, with guests gaining expansive rights in public accommodations in the United States but hosts retaining great discretion over their premises in England.

Hotels and other forms of commercial hospitality were also sites of constant disagreement and struggle over many aspects of their operation. Molly Berger, for example, has explored the technological aspects of the hotel, demonstrating how public enthusiasm for new devices and conveniences could coexist with profound fears about their effect on the citizenry. Daniel Levinson Wilk has inquired into the complex questions of labour and status that suffused hotels, showing how service workers fought against overbearing employers and resentful guests as they sought to overcome traditional notions of servitude and to find a sense of pride in their trade. Nor have such inquiries been limited to the modern age: Olivia Remie Constable's study of Mediterranean hostelries in the late classical and medieval periods reveals how they became places of intercultural contact and mutual aid-but also how in the later middle ages this more cosmopolitan orientation faded from view as public accommodations became religiously particularistic. 
A broader geographic context for our histories has also been important to our understanding of hotels because it has revealed the kinds of coercive force and hidden agendas that they represented. As the construction of large-scale public hospitality expanded beyond domestic markets and moved abroad, the meaning of hospitality often became very different. As hoteliers in Europe and the United States in the late nineteenth century constructed establishments in various overseas possessions, it was easier to see how regularly hotels played host to colonial administrators in a way that made them into instruments of imperialism. And as Annabel Jane Wharton has shown, during the Cold War the practice of commercial hospitality in developing nations became imbued with heavy geopolitical significance, with hotels becoming showcases for U.S.-style capitalism in its confrontation with Soviet communism.

In the present, with modernization theory itself having become something of a historical artefact in scholarly circles and the modernizing project encountering fierce resistance in world affairs, hotels and similar establishments that serve the public have again become flashpoints in both global and national confrontations. Around the world, hotels have continued to be targets for terrorists, fundamentalists, and others suspicious of outsiders. In the United States, the hospitality and service trades have become flashpoints of a very different kind in public debates over figurative outsiders, with opponents of gay rights, having failed to stem the tide of marriage equality, falling back to the position that they should at least be able to refuse service to gay people in public establishments.

Theoretical analyses of the hotel that were based in modernisation theory simply assumed that hotels would be found at the leading edge of epochal transformations. Historians have offered a more empirically grounded narrative: that the hotel's amazing persistence as a site of everyday contestation and conflict is its best claim as a bellwether, whatever the direction of the change it represents.

Andrew K. Sandoval-Strausz

Associate Professor of History, University of New Mexico

Distinguished Lecturer, Organization of American Historians

Distinguished Fellow, Princeton-Mellon Initiative in Architecture, Urbanism, and the Humanities, 2015-2016

\section{Professor Daniel Maudlin:}

History, Heritage and the Inn in the British Atlantic World

The aims of this short piece are, first, to position the early modern inn in relation to the modern hotel and, second, to present the two qualities that, beyond accommodating travellers, characterised inns within the early modern British Atlantic world: social rank and sociability. The subsequent fate of inns or inn heritage is also considered along the way. It is not particularly controversial to state that the early modern inn is the forebear of the modern hotel: a building (and staff) that provided hospitality in the form of overnight accommodation and meals to travellers as well a semi public gathering place for communities. The more open question is whether inns and hotels are significantly different, whether there is a clear break or a gradual 
evolution from to the other: my conclusion from extensive fieldwork surveying inns and early hotels across the Atlantic world is that it is the latter.

As in many cultures globally, inns have deep roots in British and American history. In Britain the oldest surviving inns, such as the 700 year-old George in Norton St. Phillip, Somerset, were built by the Church in the medieval period to provide accommodation for travelling clerics, pilgrims and merchants associated with the Church and its activities. In North America, records of tavern licenses date the earliest colonial inns or taverns to the early seventeenth century - the term tavern is more commonly used in North America without the British distinction whereby a tavern does not provide accommodation - with one or two extant taverns dating from the mid to late seventeenth century such as the Buckman Tavern, Lexington, Mass., c. 1690.

In the eighteenth century an inn was the centre of life in most towns and cities, providing a shared space for social, commercial, political, legal and legislative meetings as well as accommodation for travellers. From one town to the next, the inn was also a vital node in a transatlantic network of roads and settlements that extended throughout the British Atlantic Empire from Scotland to western Virginia and which from one inn to the next gave spatial and material coherence to that world. As such, an inn was an important cultural intersection where news and views were exchanged between locals and travellers.

However, from the late eighteenth century, inns across Britain and North America were superseded by hotels. Or rather, inns changed their names (and signs) from, say, the George (in Stamford, Lincolnshire) to the George Hotel or from Gadsby's Tavern (in Alexandria, Virginia) to Gadsby's Hotel. In practice, for most establishments this new name did not denote any physical changes to the building or to the spaces and activities provided inside. Indeed, the adoption of the new word 'hotel' appears to only mark the fashion for the French term 'hotel de ville' picked up by British aristocrats on the Grand Tour and adopted by canny innkeepers keen to retain (the right) customers. This new French word proved popular and by the early-nineteenth century most inns had become hotels, fitting with a deeper historical pattern whereby one of the defining characteristics of the inn as a class of building is its continuous adaptation and reinvention.

If old inns were refashioned, the first new hotels were also built in the late eighteenth century. The first establishment to open with the name 'hotel' in the English-speaking world was the Royal Clarence Hotel in the city of Exeter, south-west England, opened in 1770 and promoted as a 'hotel' by its French landlord, Pierre Berlon (sadly burned to the ground in November 2016). However, the first new hotels like the Royal Clarence were no different in size, exterior design or range of internal spaces from a large inn of the period, and can be compared to large taverns in British American cities such as Gadsby's or the City Tavern in Philadelphia. With little else changing, the shift in name from inn to hotel was a frequent cause for confusion among customers and innkeepers alike with premises advertised variously as 'inn and hotel' or 'inn-hotel'. Alexander Jenkins, described the Royal Clarence in The History and Description of the City of Exeter (London, 1806) as 'The Hotel, a large commodious Inn'. 
So, it can be argued that there was no great divide and the hotel gradually evolved from the inn, yet with a twenty-first century perspective we instinctively feel that there is a difference between the two. I argue that this is for two reasons: the increased size and scale of hostelries in the nineteenth century; and, the retrospective romantic reimagining of the pre-nineteenth century inn as exclusively 'country'. The result is an apparent gulf across which the nineteenth-century hotel appears large, grand and urban while the eighteenth-century inn or tavern appears small, humble and rural.

The nineteenth century city hotel was often significantly larger than even the grandest eighteenth-century inn. It appears to me that the fluidity and confusion of terms used by owners and customers alike to describe such establishments in the last days of preindustrial modernity suggests this increase in size was a parallel development to that of the rise of the term hotel rather than its cause. From the late eighteenth century newly-built elite establishments across the Atlantic world grew from relatively small two-to-three storey buildings, similar in scale to a high-status private dwelling, to much larger buildings more akin to public buildings in size and appearance. Road improvements and the introduction of stage coach services throughout the Atlantic world in the later eighteenth and early nineteenth century saw a massive increase in the volume of travellers - of all ranks and for multifarious reasons - and a corresponding increase in the number and size of inns/hotels. Soon, after, towards the mid nineteenth-century, the development of the railways and the growth of cities old and new - saw further new building on new sites; and, according to the fashion of the time, although fundamentally the same as an inn of the eighteenth century in their functions and spaces - bedrooms, dining rooms, assembly rooms - these new establishments were called hotels. Out of this confusion as some things changed and others stayed the same it is not clear that 'hotel' defined an entirely new type of building.

The obscuring lens of post-Romantic rural nostalgia in art and literature is the second reason we juxtapose inns and hotels: see the 'country inn' genre paintings of George Morland in Britain or John Lewis Krimmel in America, the Prancing Pony at Bree in The Lord of the Rings; or, the 'reconstructed' log-cabin Crockett Tavern Museum in Tennessee. A world of turnpikes and market and county towns, horses and carriages, nostalgically romanticised by Dickens and others in the railway age as they moved from the centre of modernity to the dusty sleepy side-lines described in Longfellow's Wayside Inn. Today, besides the physical evidence of surviving inns and taverns on both sides of the Atlantic this networked early modern, pre-industrial world can be read in place names that memorialize the site of lost inns such as the 'Turk's Head' road junction on the A30 in Somerset, southwest England; 'Old Inns' gas station near Stirling in central Scotland; 'Bear Tavern Road' near Trenton, New Jersey; or, 'Old Tavern' off exit 31 on Virginia State Route 245.

These memories focus our collective cultural imagination on the small, the rural, the cosy and the quirky (or regionally distinctive). The assumption is that early modern taverns and inns were de facto small, dirty and defined by drinking and antisocial behaviour. A satisfying juxtaposition with the nineteenth century hotel. However, throughout the British Atlantic eighteenth century hostelries and hospitality were also defined by the elite tavern or principal inn: a substantial, fasionable building that spoke of gentility, urbanity and mobility not rusticity, nostalgia and cosiness. This is 
an important distinction as if we consider the principal inn instead of the 'country inn', an alternate history emerges wherein the grand nineteenth-century hotel specifically evolved from the elite inn or tavern of the eighteenth-century. Indeed, on both sides of the Atlantic it was for the most part a town's fashionable principal inn or tavern that became its first hotel - and often still is - while the many other smaller and more regionally-inflected inns and taverns that surrounded it were reconceived as pubs or bars.

In Britain the term 'inn' described a wide range of establishments. Historians of drinking cultures have defined a 'hierarchy of victualling' that places inns at the top of a social ladder with taverns and alehouses below. A history of inns as spaces of sociability and travel suggests a more nuanced picture wherein 'inns' catered for all ranks but that not all inns were the same as there was a rigid social classification of establishments (in British America and the Caribbean the term 'tavern' was widely used to describe any licensed premises but the social distinction holds). A typical county town or port city would have supported dozens of alehouses, taverns and inns that catered to different social groups and accommodated different ranks of traveller from wagoners at one inn to gentlemen and wealthy merchants at another. At the top of this pyramid of inns was the 'principal inn' which exclusively served the social elite. In newspaper advertisements, innkeepers of principal inns appealed directly to the 'Nobility, Gentry and Commercial Gentlemen' and offered elite lures such as the 'best wines' or the fashionability implied by 'recently fitted up'. Exclusivity was also physically enforced: travelling in the 1780s the German student-traveller Karl Moritz was physically refused entry to many English principal inns because he arrived on foot and had no servant with him (so could not have been a gentleman). This equates with a similar social hierarchy of inns in Continental Europe such as the distinction between 'auberge a pied' and 'auberge au cheval' in France. An interesting contradiction to this social ordering is that as a business the early modern elite inn provided a liminal space in society for a large number of female innkeepers (often widows) as well as freed or free-born African American tavern owners in British America. Although any notion of the tavern as a democratic workspace must be tempered by the large number of slaves tied to taverns as well as the large number of slaves auctioned on the front porches of taverns.

Principal inns were typically the largest and grandest inn in town, dominating the square or main street with spaces inside such as the parlor, dining room and bar or tap room decorated and furnished in imitation of high-status domestic spaces in order to make the elite traveller feel, if not at home, then at ease in familiar surroundings. Principal inns were, therefore, expensive to operate and correspondingly expensive to stay at, further ensuring a highly exclusive clientele. The humble traveller such as a wagoner in England or pioneer family in Shenandoah who stayed at low-cost inns relatively cheap buildings built according to regional building methods - would have experienced the towns and country they travelled through as a series of distinct, diverse regions. In contrast, the elite traveller staying at principal inns would have experienced the same journey as much more of an integrated and coherent 'British' place. This is because to meet elite expectations principal inns strove to be modern, fashionable and luxurious which meant the observation of universal standards of taste through expensive, high-status materials - mahogany, linen, china and glass not pewter or wood - and buildings and contents Classically designed (or at least fashionably re-fronted and 'fitted up'). Highly decorated elite social spaces can be 
found in English inns from the late medieval period onwards and throughout the British Atlantic world by the later eighteenth century (presenting a long durée of high-status inn spaces that significantly predates the nineteenth-century hotel). That the complaints of elite travellers that dominate period travel accounts were largely directed at the common or country inns they were forced to stay at while on the road and not the (mostly urban) principal inns in which they would have stayed by preference - is overlooked in histories that have failed to take account of this social distinction. Equally, the impulse to associate tourism and resort hotels with the nineteenth century onwards should also be resisted as inns have an association with leisure travel and resorts that goes back to spas and horseracing in the seventeenth century and the polite tourist in search of the Picturesque in the eighteenth.

Like the hotel, the early modern inn was also an important site of leisure and sociability for the town - the community - it served providing small and large spaces for social gatherings from business and legal proceedings to weddings and dinner with friends. Here, it is a mistake to think of the inn or tavern only in relation to the consumption of alcohol and drinking cultures documented by licensing laws, licenses and court records. In contrast, newspaper records reveal a history of sociability that was much more diverse than this. Across the British Atlantic world, principal inns served tea to temperance society meetings, dinner to learned astronomical societies, and welcomed ladies to cotillion dances in richly decorated assembly rooms as much as they served rum punch to all-male political meetings. At the centre of civic life, the urban spatial matrix of inn, church and court-house places sociability - meeting for informal and formal gatherings accompanied by food, drink and dancing - alongside religion and the law as a cornerstone of eighteenth-century life. Indeed, while there was not always a church or court-house there was nearly always a principal inn (in many cases hosting temporary court sessions as well as providing judges' lodgings). Here, a distinction can be identified between the inn and the hotel, in that the inn was more central to early modern urban life. While hotels continue to host business meetings and weddings the explosion of diverse sites for leisure activities and civic functions in most towns has diluted the singular position and status the inn-hotel previously occupied. In present day Britain these buildings are mostly still working hotels, while in North America while many historic taverns still exist they are more likely to be private houses or tavern museums (a form of heritage site not found in the UK where even those historic inns owned by the National Trust are operated as working pubs).

In this short piece I have argued that in Britain and North America the first hotels evolved from elite inns and taverns and that at the top of the social hierarchy of victualling the change in name from inn to hotel denotes fashionable terminology more than a specific correlation to any immediate changes in form or function. Indeed many early hotels were old inns with new names. As such, in looking at a history of hostelry in Britain and North America, (elite) inns and hotels are not two distinct things but phases in a long cultural history of hospitality defined by constant change and continuous adaptation to the times - often in the same building - in which a change of name or an increase in size mark both changing social and economic demands and the innkeeper's perpetual desire to meet the expectations of customers.

Professor Daniel Maudlin

School of Humanities and Performing Arts 
Faculty of Arts \& Humanities

Plymouth University

\section{Professor Maurizio Peleggi:}

Hotel history as a field of academic enquiry (as distinct from marketing exercises) is still in its infancy, the only international history to date being still Elaine Denby's book of $1988 .{ }^{1}$ The following considerations on the wide-ranging historiographical import of hotel history are informed from the disciplinary perspective of social and cultural history and the particular geographical perspective of Southeast Asia, a region which until the end of World War II was apportioned between three colonial powers-Britain (Burma), France (Indochina, including present-day Laos, Vietnam and Cambodia) and the Netherlands (Indonesia). To these one must add the United States, which gained control of the Philippines from Spain in 1898 and administered it as a de facto colony until 1935. The kingdom of Siam (Thailand) was also, despite its formally independent status, conditioned to a great extent by the colonial powers.

The history of the modern hospitality industry in Southeast Asia is thus, as in most of the non-Western world, a particular aspect of the social, cultural and economic history of Western imperialism The decades from ca. 1900 to 1920 saw the foundation of modern tourist infrastructures in Southeast Asia; European-style 'grand' hotels opened in the region's colonial capitals as well as in recreational localities specially designed for the colonials, e.g. hill stations (which have attracted much more scholarly attention than hotels due to their institutional origins, hence availability of relevant archival sources). The tourism industry's central position in the current Southeast Asian economy underscores the import of colonial-era tourism and its legacy, hence its significance as an object of historical enquiry. Indeed, in the 1990s several extant colonial-era hotels in Singapore, Malaysia, Thailand, Vietnam, Cambodia and Myanmar were renovated and commercially re-launched targeting a specific subset of the tourism market's upper segment: nostalgia-seeking tourists. ${ }^{2}$

Within the limited space mandated for this contribution I shall focus on two areas of research to which hotel history bears special relevance. The first, more obvious, is the study of the history of the transfer of technology and industrial and managerial knowhow, ${ }^{3}$ as well as the diffusion of consumer habits, from the métropoles to the colonies. The second area is the study of racial, class and gender dynamics within the plural society of the colonies.

\footnotetext{
${ }^{1}$ E. Denby, Grand Hotel, Reality and Illusion: A Cultural and Architectural History (London: Reaktion, 1988).

${ }^{2}$ M. Peleggi, "Consuming Colonial Nostalgia: The Monumentalization of Historic Hotels in Urban Southeast Asia," Asia-Pacific Viewpoint 46,3 (2005): 255-65. ${ }^{3}$ This area of research was pioneered by D. R. Headrick in The Tools of Empire: Technology and European Imperialism in the Nineteenth Century (Oxford: OUP 1981); and The Tentacles of Progress: Technology Transfer in the Age of Imperialism, 1850-1940 (Oxford: OUP, 1988). See also M. Adas, Machines as the Measure of Men: Science, Technology, and Ideologies of Western Dominance (Ithaca, NY: Cornell University, 1989).
} 
Over the course of the nineteenth century the hospitality industry in the Western colonies of Southeast Asia developed from inns and boarding houses to modern hotels that offered standards of design, technology, comfort and entertainment on a pair with those of metropolitan hotels. Hotels were often the first electrified buildings in colonial cities thanks to in-house generators, and offered hot and cold running water (which even in European and North American hotels became available only in the early 1900s) and refrigerated rooms for food storage, which made available in tropical climates meat and dairy products that were central to the colonials' diet, hence to their self-identification and distinction from indigenous people (gastronomic hybridization was extremely limited in the British and French colonies, somewhat less so in the Dutch East Indies). Moreover, hotels' shopping arcades provided access to imported luxury goods and modern consumer services, such as Thomas Cook \& Son's travel agency and Reuter's Telegrams. Hotels were also venues of cultural innovation: in the main cities of Southeast Asia film screenings and jazz bands made their debut in hotel theatres. It is surprising, therefore that hotels are only rarely mentioned in the copious academic literature on colonial urbanism and architecture published in the last two decades. ${ }^{4}$

Comfort zones by design and commercial purpose, hotels in colonial cities were also prominent 'contact zones' (in Marie-Louise Pratt's phrase ${ }^{5}$ ): spaces of interaction between the different groups of people who lived in colonial cities. Hotel history provides thus valuable insights into the social dynamics of the plural colonial society, a dimension of the colonial experience investigated most productively by Ann Laura Stoler. ${ }^{6}$ Hotel history may shed light on the interactions between dominant Europeans and subjected Asians, but also, and most intriguingly, between national, social, ethnic and gender subgroups within each of them (e.g., lower class male and female Europeans and Chinese male immigrants), as well as diasporic communities that thrived in the British empire, e.g., Armenians, who were prominent among hotel owners and managers in Southeast Asia.

These complex dynamics can be visualized here by two images: one is drawn from the hotel's interior space, the other, instead, from the urban space surrounding it. Restaurants and ballrooms became central to the social life of colonial elites, providing suitable venues for their socializing rituals but also for the display and reinforcement of social distinctions. A chronicler of colonial Singapore's social life stressed the difference in status between customers who attended diners dansants at The Europe Hotel (the city's premier hotel in the 1920s) on weekly evenings and on Saturday. After brothels were outlawed in Singapore in 1930, European prostitutes moved their operations to cheap hotels and rented rooms, and even solicited in the streets on board of rickshaws. In those same years this means of transportation

\footnotetext{
${ }^{4}$ See E. T. Jennings, 'From Indochine to Indochic: The Lang Biat/Dalat Palace Hotel and French Colonial Leisure, Power and Culture', Modern Asian Studies 31,1 (2003): 159-94; M. Peleggi, 'The Social and Material Life of Colonial Hotels: Comfort Zones as Contact Zones in British Colombo and Singapore, ca. 1870-1930', Journal of Social History (2012).

${ }^{5}$ M.-L. Pratt, Imperial Eyes: Travel Writing and Transculturation (London: Routledge, 1992).

${ }^{6}$ A. L. Stoler, Carnal Knowledge and imperial Power: Race and the Intimate in Colonial Rule (2nd ed. Berkeley, CA: University of California Press, 2010).
} 
operated by Chinese coolies was being progressively phased out because it hindered motorcar traffic. Forced into invisibility and obsolescence despite the great demand for their services by both colonial residents and tourists, prostitutes and rickshaw pullers joined forces to reassert their presence in Singapore's central district, where grand hotels constituted reservoirs of potential customers for both. As contact zones, colonial hotels allowed within and around its space a variety of intimacies that the colonial city's spatial boundaries were supposed to prevent.

Finally, hotel history is of great relevance to the study of the phenomenon termed 'colonial modernity' that marked the interwar years, in which politics, economics, technology, and social and cultural change intersect. Hotels played, as sites of conspicuous consumption and commercial leisure, a different role in metropolitan centres and in the colonies. In the former context, access was determined by economic capital - that is, class; in the latter, the class divide was redoubled by race - only few grand hotels in Asia accepted elite Asian patrons, even as Asian workers were essential for the functioning of colonial hotels. These circumstances eventually led, in the 1930s, to the creation in the cities of Southeast Asian cities of more inclusive spatial economy of leisure (including cinemas, dancing halls and open-air amusement parks), where bright lights, music and the promise of romance were finally available to both ordinary colonials and Asians of various ethnicities. For all these reasons, one can only hope scholars will start paying more attention to the far from secondary role hotels played in the formation of colonial modernity.

Maurizio Peleggi

Associate Professor of History

National University of Singapore

\section{Dr. Cédric Humair:}

\section{Hotel History: Towards diversification}

Jadis, le tourisme était l'art égoïste de bien voyager. Aujourd'hui, il est devenu l'industrie nationale de bien recevoir. Il en résulte qu'il est passé, tout d'un bloc, du domaine de l'agrément individuel ou collectif, à celui de l'économie générale. Léon Auscher, Vice-président du Touring-Club de France $1917 .{ }^{7}$

Over the last thirty years, historiographical reviews of tourism have paid little attention to the hotel sector's history. ${ }^{8}$ What a surprising observation, since

\footnotetext{
${ }^{7}$ Quoted in Bertrand Larique, L'économie du tourisme en France des années 1890 à la veille de la Seconde guerre mondiale. Organisation et développement d'un secteur socio-économique, (PhD dissertation, Bordeaux : Université de Bordeaux III, 2006), 5.

${ }^{8}$ Richard Butler and Geoffrey Wall, "Introduction : themes in research on the evolution of tourism", Annals of Tourism Research 12 (1985), 287-296 ; John K. Walton, "Histories of tourism", in The SAGE Handbook of Tourism Studies, eds., Tazim Jamal and Mike Robinson (Los Angeles : SAGE, 2009), 115-129 ; Hasso Spode, "La recherche historique sur le tourisme. Vers une nouvelle approche", Mondes du tourisme 2 (2010), 4-18.
} 
accommodation is one of the three basic services - with mobility and recreation necessary for tourism. In general, large historical studies on tourism development did not accord much importance to hotels, focusing on evolutions of tourists' activities and ways to travel. How do we explain this situation? One of the main reasons is that, in Europe, the topic was mainly investigated by historians devoted to arts and architecture who developed more aesthetic and symbolic approaches centred on buildings and equipment. The oft-cited, seminal work of Nikolaus Pevsner, a historian of architecture, was dedicated to elaborating the buildings' typology. ${ }^{9}$ The relevance of these studies for understanding tourism development was limited, and so they were largely ignored by academics working on this topic. That bias was strong in Switzerland, for example, although it was one of the earlier European countries to build big hotels closely linked to tourism development (Hôtel des Bergues in Geneva in 1834). ${ }^{10}$ While historians deserted the field, art and architecture analysts realised the main contributions to hotel history. ${ }^{11}$ In the United States, the historiography on hotels is older and more developed. ${ }^{12}$ However, the analysis centred on the grand hotels built in big cities, whose connections with tourism development was, most of the time, weak. The strongest argument was to show the hotel as a symbol of modernity and a vector of prestige. This tradition is still strongly rooted in AngloSaxon historiography. ${ }^{13}$

Over the last two decades, however, this situation has changed. First, historians' interest in tourism has increased, leaving more space for the development of studies centred on, or taking into account, the hotel sector. ${ }^{14}$ Congresses dedicated to tourism history have flourished, some giving space to the accommodation question. Second, congresses and special sessions of international conferences have been dedicated to the hotel sector's history. ${ }^{15}$ As a result, the historiography on the topic has expanded

\footnotetext{
${ }^{9}$ Nikolaus Pevsner, A History of Building Types (Princeton : Princeton University Press, 1976) ; the chapter 11 is dedicated to hotels.

${ }^{10}$ For an analyse of the Swiss case, see Laurent Tissot, "D'une Suisse aimée à la
} Suisse aimante. Tourisme, transport et mobilité dans l'historiographie économique de la Suisse aux $19^{\mathrm{e}}$ et $20^{\mathrm{e}}$ siècles", Traverse. Revue d'histoire 1 (2010), 156-170 (here 164-165).

${ }^{11}$ See the studies of Roland Flückiger-Seiler : the last is Berghotels zwischen Alpweide und Gipfelkreuz. Alpiner Tourismus und Hotelbau 1830-1920 (Baden : Hier und Jetzt, 2015).

${ }^{12}$ See the studies of Doris Elizabeth King : for example "The First-Class Hotel and the Age of the Common Man", The Journal of Southern History, 23/2 (1957), 173188.

${ }^{13}$ A.K.Sandoval-Strausz, Hotel: An American History (New Haven : Yale University Press, 2006) ; Molly Berger, Hotel Dreams: Luxury, Technology, and Urban

Ambition in America, 1829-1929 (Baltimore : John Hopkins University Press, 2011).

${ }^{14}$ See the studies of the following historians: John Walton (Great Britain), Annunziata Berrino and Patrizia Battilani (Italy), Carlos Larrinaga (Spain), Laurent Tissot (Switzerland), Hans Heiss (Germany), Christophe Bouneau and Marc Boyer (France), Andrea Leonardi (Austria), Margarita Dritsas (Greece).

${ }^{15}$ In chronological order : XVth World Economic History Congress in Utrecht 2009, panel organized by Laurent Tissot and Margarita Dritsas : Hotel Industry in a Long Historical Perspective : Forms, Governance and Actors (18th-21st centuries); 11th International Conference on Urban History in Prague 2012, session organized by 
quickly, and so too has academic research. In 2011, for example, the Italian review Storia del turismo dedicated a special issue to tourist companies, with five contributions on the hotel sector ${ }^{16}$. Furthermore, several $\mathrm{PhD}$ dissertations have been realised in hotel sector history and others are still going on. At the University of Neuchâtel, a three-year research project dedicated to the Swiss hotel industry during the Interwar period is currently underway. ${ }^{17}$ Another result was the diversification of research question and approaches - economic, social and political histories are now better represented. If this short contribution is unable to cover all the aspects of this burgeoning field, it will nevertheless identify some topics recently developed by historians, in focusing mainly on French-speaking historiography, but with incursions into Italian, German and Anglo-Saxon historiographies.

The main subject of the existing historiography, the grand hotel, has been analysed in many ways during the last years. Economic approaches which consider grand hotels as enterprises and show their functioning in a highly capitalized economy have underline the specificities of such companies. In all the case studies, the common quality necessary to the hotels' success was identified as a high capacity for adaptation. In analysing the Hôtel Bellevue in Brussels during a long period (17761905), ${ }^{18}$ for instance, Virginie Jourdain shows how its functions were progressively adapted to changing social and economic contexts; so did Hans Heiss's study of the Hotel Elephant in Brixen (Tyrol) between 1551 and 2001. ${ }^{19}$ With his $\mathrm{PhD}$ dissertation on the Grand Hôtel de Paris, ${ }^{20}$ Alexandre Tessier underlines the financial challenges that produced continual to technological evolutions, and adaptations to meet new comfort standards. Mary Quek has dealt with the capacity of the Hilton group to face a crisis in its process of internationalisation. ${ }^{21}$ Let us note also the interesting renewal in the traditional commemorative approach to hotel history. In an edited collection on Beau-Rivage Palace in Lausanne, Nadja Maillard gathered historians employing

Laura Kolbe : Grand Hotel and the City; Grand Hotels at the Fin de Siecle : global perspectives, local experiences in Berlin 2013, organized by Botakoz Kassymbekova (Center for Metropolitan Studies); The Grand Hotels as the Powerhouses of Change between 1870 and 1930: an Investigation of the Alpine and Subalpine Areas, from the Lakes to the Mountains in Riva del Garda 2015, organized by Monica Aresi (Museo Alto Garda).

${ }^{16}$ Patrizia Battilani (ed.), Le Imprese, Soria del turismo, 8 (2011).

${ }^{17}$ The project is directed by Laurent Tissot : L'industrie hôtelière suisse dans la première moitié du XXe siècle : un modèle en crise ? Configurations, espaces et usages, https://www2.unine.ch/histoire/page-30397.html .

${ }^{18}$ Virginie Jourdain, L'hôtel Bellevue - 1776-1905. Précurseur de l'hôtellerie de luxe à Bruxelles (Bruxelles: Archives de la Ville de Bruxelles, 2008).

${ }^{19}$ Hans Heiss, Der Weg des Elephanten, Geschichte eines großen Gasthofs seit 1551 (Wien : Folio, 2002).

${ }^{20}$ Alexandre Tessier, Le Grand Hôtel: l'invention du luxe hôtelier, 1862-1972

(Rennes: Presses Universitaires de Rennes, 2012).

${ }^{21}$ Mary Quek, "Re-organisation of Hilton Hotels International, 1958-1959 : a Reactive Crisis Approach ", in Tourism and Crisis in Europe XIX - XXI centuries. Historical, National, Business Perspectives, ed., Dritsas Margarita (Athens : Kerkyra Publications-economia Publishing, 2014), 102-115. 
economical, social, political and cultural approaches. ${ }^{22}$ This grand hotel was analysed in complex ways, both in terms of its inner functioning and its multiple relations with the outside. At least from the end of the nineteenth century, the success of highquality hotels was conditioned by efficient management and employees' training. Andrea Zanini and Aldo Carera develop these questions in Italian studies. ${ }^{23}$

The most dynamic field in hotel sector history explores the dialectic between hotel and cities. Besides the numerous approaches developed by geographers on tourism and urbanisation, which cannot be detailed here, several historians analyse the hotel sector on a urban scale, pushing the historiography out of its strong focus on grand hotels. Two books dealing with Paris, by Daniel Roche et $\mathrm{al}^{24}$ and Jean-Marc Lesur, ${ }^{25}$ follow the hotel's evolution and map out, in detail, its actors over the long term (the seventeenth to the twentieth centuries). They show, from the perspective of urban history, the economic and social importance of this sector in connection with the gestation of diverse mobilities. Using modern technologies for analysing the spatiality of the hotel fabric in Milan and Brussels, the PhD dissertations of Giuliana Geronimo $^{26}$ and Virginie Jourdain ${ }^{27}$ are especially important from a methodological point of view in offering several innovative documentary solutions for a reconstruction of the hotel market in the past. An especially impressive diversity of documents has been used by Virginie Jourdain for the construction of a typology of the different kinds of accommodation. Giuliana Geronimo proposes, among others, a sociological analysis of the hotel entrepreneurs. The two contributions of Laurent Tissot dedicated to Lausanne and Geneva are more centred on relations between hotels and tourism. ${ }^{28}$ In the case of Lausanne, a quantitative approach coupled with a

${ }^{22}$ Nadja Maillard (dir.), Beau-Rivage Palace, 150 Years of History (Lausanne : Infolio, 2008).

${ }^{23}$ Andrea Zanini (2012b), "Formazione professionale e sviluppo: gli esordi dell'istruzione alberghiera in Italia", Società e Storia 136 (2012), 355-386 ; Andrea Zanini, "L'evoluzione di un family business fra tradizione e innovazione : gli Alberghi Fioroni a Genova (1897-1939)", Soria del turismo 8 (2011), 45-70 ; Aldo Carera, "Stili di management alberghiero sui laghi prealpini lombardi (XIX-XX sec.)", in Turismo e sviluppo in area alpina. Secoli XVIII-XX, eds., Andrea Leonardi and Hans Heiss (Innsbruck : Studien Verlag, 2003), 319-370.

${ }^{24}$ Daniel Roche et alii, La ville promise. Mobilité et accueil à Paris (fin XVIIème-début XIXème siècle) (Paris : Fayard, 2001).

${ }^{25}$ Jean-Marc Lesur, Les hôtels de Paris. De l'auberge au palace, XIXe-XXe siècles (Neuchâtel : Alphil, 2005).

${ }^{26}$ Giuliana Geronimo, Milano ospitale 1827-1914. Storia et storie di un secolo degli alberghi milanesi con cartografia storica e nuove tecnologie Web-GIS, Università di Bologna (2008), consulted 20.04.2016 http://amsdottorato.unibo.it/1146/1/Tesi_Geronimo_Giuliana.pdf.

${ }^{27}$ Virginie Jourdain, L'hôtellerie bruxelloise 1880-1940. Acteurs, structures et logiques spatiales d'un secteur multiforme, Université libre de Bruxelles / Université de Neuchâtel (2011-2012), consulted 20.04.2016 https://doc.rero.ch/record/29555/files/00002262.pdf

${ }^{28}$ Laurent Tissot, "Hôtels, pensions, pensionnats et cliniques : fondement pour une histoire de «l'industrie des étrangers » à Lausanne, 1850-1920 ", in, Le passé du présent. Mélanges offerts à André Lasserre, eds., Brigitte Studer et alii (Lausanne : 
spatial analysis shows the evolution of the accommodation market in relation to tourism, transport and city developments. In the case of Geneva, Tissot shows how the presence and the concentration of high-standard hotels contributed to create a space dedicated to luxury services in the city.

The hotel sector is also integrated in analysis on a larger spatial scale, contributing, in some cases, to the renewal of the framework of "regional history". With his article on early tourism in Bernese Alps, Beat Kümin argues that the landscape was not the only important factor in explaining the success story of a tourism region; so too was the quality of the accommodation. ${ }^{29}$ This approach was developed and enlarged by Cédric Humair et al in their study on the Lake Geneva region, ${ }^{30}$ following two main lines of inquiry: (1) how diverse "capitals" necessary for an efficient hotel sector (investments, 'know how', political influence, etc.) were mobilised; and (2), by means of biographical and companies databases, the interconnections of actors in the accommodation sector with financial, technical, medical and political ones. The result is a better understanding of the hotel sector's functions in a larger tourist system, including the role of actors inside and outside the region. From that same perspective of mobilizing the necessary expertise, a study of the mobility of Swiss hoteliers, which played an important role in the development of some regions, has been undertaken by Ewa Kawamura for Italy. ${ }^{31}$ Patrizia Battilani, working on the Mediterranean (Spain, France, Italy), shows how massification of tourism was connected to the emergence of a new class of hoteliers operating small and mid-sized accommodation structures. ${ }^{32}$

Another interesting research direction is the analysis of the economic, and also technical, social and cultural, spin-off effects of hotel-sector - and more generally tourism - development, on local, regional or national scales. Admittedly, this approach is not novel, but is historically associated with tourism actors advocating support of the sector through state intervention. Focussed on the Rimini district, the studies of Patrizia Battilani and Francesca Fauri analyse the relations between hotel construction and industrialization. ${ }^{33}$ In the Lake Geneva region, as Cédric Humair

Editions Payot, 1999), 69-88 ; Laurent Tissot, “L'hôtellerie de luxe à Genève (18302000). De ses espaces à ses usages", Entreprises et histoire 46 (avril 2007), 17-34.

${ }^{29}$ Beat Kümin, "Vormodernes Gastgewerbe und früher Tourismus in den bernischen Alpen", in Turismo e sviluppo in area alpina. Secoli XVIII-XX, eds., Andrea Leonardi, Hans Heiss (Innsbruck : Studien Verlag, 2003), 281-300.

${ }^{30}$ Cédric Humair, Marc Gigase, Julie Lapointe Guigoz, Stefano Sulmoni, Système touristique et culture technique dans l'Arc lémanique: analyse d'une success story et de ses effets sur l'économie régionale (1852-1914) (Neuchâtel : Alphil, 2014).

${ }^{31}$ Ewa Kawamura, "Alberghi e albergatori svizzeri in Italia tra Ottocento e Novecento", Storia del turismo. Annale 2003, 4 (2004), 11-21.

${ }^{32}$ Patrizia Battilani, "Des grands hôtels aux entreprises familiales : la transition vers le tourisme de masse dans les pays de la Méditerranée", Entreprises et histoire 47 (juin 2007), 26-43.

${ }^{33}$ Patrizia Battilani and Francesca Fauri, "The rise of a service-based economy and its transformation: seaside tourism and the case of Rimini", Journal of Tourism History 1 (March 2009), 27-48 ; Patrizia Battilani and Francesca Fauri, "Il turismo come motore dello sviluppo economico locale: il caso di Rimini”, Storia del turismo. Annale 2004, 5 (2005), 61-87. 
shows, hotel sector growth was closely connected with the development of luxury goods industries, capital goods industries and private banking. ${ }^{34}$ Finally, Andrea Leonardi shows both how grand hotels generated tourism development, and how tourism development gave a strong impetus to the modernization of the alpine economy. ${ }^{35}$ Indeed, several scholars have underlined the role played by hotel industry in the circulation of technics and the implementation of technical networks (water, energy, communications, and transport) ${ }^{36}$ In several articles, Julie Lapointe Guigoz, for instance, has underlined innovation in the running of grand hotels and the effects of that structural requirement on companies and social environment. ${ }^{37}$

Recent research also highlights financial aspects of hotel sector history, even though this question remains largely underdeveloped. The first important question is: who invested in hotel industry ? Gianluca Giannico analyses the evolution of the investors in southern Italy, underlining the exogenous contribution coming from Milan. ${ }^{38} \mathrm{In}$ contrast, Julie Lapointe Guigoz shows that hotel development in the Lake Geneva Lake region was essentially endogenous. At the end of the nineteenth century, regional private bankers and hoteliers collaborated to create nearly fifty stock companies able to finance the adaptation to rapid evolution of technics and the comfort standards wanted by the customers. ${ }^{39}$ Another question centres on the financial results of hotel companies and the profitability of their investments. Laurent

${ }^{34}$ Cédric Humair, "The hotel industry and its importance in the technical and economic development of a region : the Lake Geneva case (1852-1914)", Journal of Tourism History, 3 (2011), 237-265.

${ }^{35}$ Andrea Leonardi, "I Grand Hotel come motore dello sviluppo turistico in area alpina", paper presented at the conference The Grand Hotels as the Powerhouses of Change between 1870 and 1930, Riva del Garda 2015 ; Andrea Leonardi, "Turismo e modernizzazione economica nell'area alpina austriaca", in Turismo e sviluppo in area alpina. Secoli XVIII-XX, eds., Andrea Leonardi, Hans Heiss (Innsbruck : Studien Verlag, 2003), 227-280.

${ }^{36}$ See for example the contributions of Richard Gassan, Bernd Kreuzer, Alexandre Tessier, François Breuillaud-Sottas and Piergiuseppe Esposito in Le tourisme comme facteur de transformations économiques, techniques et sociales (19e-20e siècles) /Tourism as a factor of economic, technical and social transformations (19th-20th centuries), eds., Marc Gigase, Cédric Humair, Laurent Tissot (Neuchâtel : Alphil, 2014).

${ }^{37}$ Julie Lapointe Guigoz, "L'innovation technique au service du développement hôtelier : le cas des ascenseurs hydrauliques dans l'Arc lémanique (1867-1914)", in Le tourisme suisse et son rayonnement international (XIXe-XXe siècles). " Switzerland, the playground of the world », eds., Cédric Humair and Laurent Tissot (Lausanne : Antipodes, 2011), 111-133 ; Julie Lapointe Guigoz, "Les innovations techniques des grands hôtels veveysans du XIXe siècle : un facteur de succès", Les Annales Veveysannes 15 (2014), 56-79.

${ }^{38}$ Gianluca Giannico, "Investimenti nella ricettività alberghiera nel sud Italia: dai primi albergatori di Capri all'arrivo dei "milanesi"', Storia del turismo. Annale 20056 (2006), 35-52.

${ }^{39}$ Julie Lapointe, "Les sociétés anonymes à vocation hôtelière de l'Arc lémanique (1826-1914)", in Le client de l'architecte. Du notable à la société immobilière : les mutations du maître de l'ouvrage en Suisse au XIX siècle, ed., Dave Lüthi (Lausanne : Études de Lettres, 2010), 211-240. 
Tisso/Cédric Humair ${ }^{40}$ and Alexandre Tessier ${ }^{41}$ propose some answers in their case studies on Beau-Rivage Palace in Ouchy and the Grand Hôtel in Paris, respectively. Based on the hotel companies quoted in stock market in Geneva and Lausanne during the Belle Epoque, the analysis of Cédric Humair et al ${ }^{42}$ shows the average profitability of grand hotels during the period using two indicators: share value and the distribution of dividends.

Finally, it is important to underscore the hotel sector's development in terms of its political dimensions. The development and the activities of hoteliers' organisations as important actors of the construction of a competitive accommodation market is a critical consideration. Realised in a five-year program on European business organisations, several contributions proposed by Andrea Zanini and Marco Teodori for Italy and Mathieu Narindal and Cédric Humair for Switzerland, underline the role played by these actors as coordinators of the hotel companies and as conduits to public communities for managing their intervention. ${ }^{43}$ Of particular interest for understanding the hotel sector's evolution are documents dedicated to market regulation. ${ }^{44} \mathrm{~A}$ second topic is the intervention of public collectivities, at different levels, in the hotel sector. In Italy, for example, Marco Teodori and Elisa Tizzoni explore state policies during the interwar period. ${ }^{45}$ Finally, John Walton considers tourist resorts and the grand hotels as important places for the understanding of political events and evolutions. ${ }^{46}$

\footnotetext{
${ }^{40}$ See their two contributions in Nadja Maillard, op. cit., 62-76 and 82-100.

${ }^{41}$ Alexandre Tessier, op. cit.

${ }^{42}$ Cédric Humair, Marc Gigase, Julie Lapointe Guigoz, Stefano Sulmoni, op. cit., 359-364.
}

${ }^{43}$ See their contributions in the four books published between 2012 and 2016 under the direction of Danièle Fraboulet and Pierre Vernus and edited by the Presses Universitaires de Rennes.

${ }^{44}$ Marco Teodori and Andrea Zanini, “Autorégulation versus intervention gouvernementale. L'Association italienne des hôteliers et le marché de l'hospitalité (1899-1939)", in Réguler l'économie. L'apport des organisations patronales. Europe, XIXe-XXe siècles, eds., Danièle Fraboulet, Michel Margairaz and Pierre Vernus, (Rennes : Presses Universitaires de Rennes, 2016), 113-126 ; Humair Cédric et Narindal Mathieu, "Les organisations patronales suisses de l'hôtellerie et la cartellisation du marché : des premières initiatives locales à l'instauration d'un système national en collaboration avec l'Etat (1879-1939)", in idem, 95-112.

${ }^{45}$ Marco Teodori, "La politica economica dell'accoglienza. La legislazione turisticoalberghiera in Italia tra le due guerre, in Tra vecchi e nuovi equilibri. Domanda e offerta di servizi in Italia in età moderna e contemporanea, Iginia Lopane and Ezio Ritrovato (ed.) (Bari : Cacucci, 2007), 551-566; Elisa Tizzoni, "Politiche statali a favore della ricettività turistica tra le due guerre in Italia : i dopolavoristi della KDF in Versilia", Storia del turismo 8 (2011), 181-200.

${ }^{46}$ John K. Walton, "Tourism and politics in elite beach resorts: San Sebastián and Ostend, 1830-1939", in Construction of a Tourism Industry in the 19th and 20th century: international perspectives, ed., Laurent Tissot, (Neuchâtel : Alphil, 2003), 287-301 ; John K. Walton, "Grand hotels and great events: history, heritage and hospitality", in Beau-Rivage Palace: 150 Years of History, ed., Nadja Maillard (Lausanne: Payot, 2008), 102- 12. 
In conclusion, it is no exaggeration to assert that hotel history is essential for the understanding of tourism development and cultures of hospitality. Even if the field is still in development, burgeoning interest in the aspects of social, economic and political history offer several lines of inquiry to be exploited, intensified and diversified.

Cédric Humair

University of Lausanne

\section{Professor Molly Berger:}

Facebook in many ways has become host to a form of travel memoir, beginning with a clever map-based graphic that charts an imminent flight from one city to another, continuing with well-placed selfies, curated photos of perfect meals, landscapes, and exotic scenes, and ending with reassurances to friends and family that one has finally arrived home, safe and sound. That Facebook travel stories so rarely include images of hotels or hotel rooms speaks to questions about hotels and how they seem so transparent, not needing any sort of critical analysis or explanation. Nor do they rise to Facebook worthiness, unless, of course, the hotel is super chic and conveys a status marker for the traveler. After all, we travel, we need a place to sleep and perhaps eat, we rent a hotel room. What more is there to know? As scholarship in the last ten years or so has demonstrated, there is quite a bit to know; histories have revealed entanglements in political ideology, economic imperatives, and social and cultural practices. I am looking forward to seeing how current and future investigations will build on the initial and consequential histories that established hotels as valuable sites for historical inquiry.

My own work focuses on nineteenth and early-twentieth century American luxury hotels, their development, and the way that cutting-edge technological innovation served to construct a narrative of progress for the buildings, the developers, and most importantly, their cities. In the nineteenth century and well into the twentieth century, newspapers devoted full pages, even special sections, to describing every detail of a newly opened hotel. The hotels themselves published beautifully printed souvenir booklets that similarly described not just the furnishings, but also the 'mechanical departments' such as furnaces and boilers, laundries, elevators, kitchens, communication systems, loading docks, and service quarters. While the guest quarters guaranteed a level of comfort and sophistication, the systems that made up the back of the house represented participation and, indeed, leadership in the world of commerce, manufacturing, and innovation, and perhaps most importantly served as a symbol of 'American know-how'.

In 2016, as my hometown, Cleveland, Ohio, prepared to host the Republican National Convention, articles that echoed these historical precedents were on display once more on the front pages of the local newspaper. During the months leading up to the convention, three new hotels opened in the heart of downtown. Two are restored and repurposed early twentieth-century landmark buildings and the third is a shiny glass structure that projects contemporary sensibilities. As I read the enthusiastic newspaper descriptions, I was reminded of similar nineteenth-century accolades bestowed on the newest, fanciest, and most serviceable hotels of the time. Like their earlier counterparts, the new Cleveland hotels promise convenience, central location, the 
latest in technological amenities and comfort, and a degree of luxury that not only eases the feelings of displacement borne by a certain class of travelers, but also confers status on all who stay and on the city itself. Instead of boasting of indoor plumbing, central heating, and mechanized laundries - technologies we take for granted-new hotels assure travelers of high speed wi-fi connections, 55-inch LCD TVs, fingertip control panels, and fitness rooms. As in the past, hotels around the world are often the leading edge on revolutionary technologies, such as robots that serve as concierges, receptionists, and delivery personnel. Do these kinds of technologies add value to a guest's experience or do they work against expectations for hospitality's personal touch or invite inevitable frustration when a guest can't figure out how the bathroom fixtures work or why "the no longer seen as necessary" landline has disappeared from the guest room? ${ }^{47}$

Looking at hotels through the lens of technology is just one way to understand the imperatives behind renovations and new hotel buildings. The Ritz Paris shut down for nearly four years, not solely for a facelift, but also to completely redo all the technological systems of the 118-year old building, including the upgrade of plumbing, heating and cooling, high-speed wi-fi, and other systems. ${ }^{48}$ Donald J. Trump's newest hotel, the Trump International Hotel in Washington, D.C., a repurposing of the Old Post Office Pavilion on Pennsylvania Avenue, promises unprecedented luxury characterized by opulent furnishings and oversized guest rooms with five-fixture bathrooms (even I can't guess what the fifth fixture is; the suites have SIX-fixture bathrooms). The 4,000 square foot suite is purported to be three times larger than the Oval Office a statement of braggadocio with an implied hierarchical cultural value. In an op-ed piece in the September 23, 2016 New York Times, Elizabeth Williamson noted that 'just walking through the door seems like a political act'. Guest rooms that were to have sold for $\$ 895$ per night are now advertised starting at $\$ 396$. The shiny gold Trump name that adorns the hotel is reminiscent of the Vanderbilt and Astor families at the turn of the twentieth century when they colonized New York City with their homes and hotels. The Trump International Hotel's website boasts - with or without irony- that 'Washington will never be the same.' The point is that technology opens one part of the story, but all stories require social and cultural context.

A large hotel is formidable in its complexity. Not only does it provide that proverbial 'home away from home', but also meals, housekeeping, air quality, reliable plumbing, meeting spaces for business and tourists, accurate accounting, personal service, safety, access to its host community and transportation and much more. The list is endless. But, lists only go so far in unpacking the complexity. Each building, no matter how grand or commonplace, has both a biography and a context. The biography might include its development: who owns the land? who are the investors? the management? the architect? What are the systemic economic and political structures that underwrite this project? What is the imperative and incentive for building this hotel in this place at this time? Who is the target market? The answers to

\footnotetext{
${ }^{47}$ Matthew Kronsberg, “Are High-Tech Hotels Alluring_or Alienating?” The Wall Street Journal, (28 April, 2016), http://www.wsj.com/articles/are-high-tech-hotelsalluringor-alienating-1461866041.

${ }^{48}$ Shivani Vora, "Ritz Paris is Ready for Action," The New York Times (5 June 2016), TR 13.
} 
these questions are rarely straightforward or clear and often represent political and economic struggles for power and control. Anyone who paid even a little attention to the 2016 United States presidential election knows that answering these questions can lead to a trail of deals and well-constructed public narratives meant to obfuscate background negotiations. And we also need to ask - as this roundtable asks - if this biography is told most aptly through a local, national, or transnational lens.

As relevant, if not more so, are the social and cultural categories of inquiry informed by race, class, and gender. As these categories have become more fluid and intersectional, how does our understanding of how hotels work and how people function within them expand and change? Have hotels, their management, service workers, guests, and spaces become more or less rigid as social and cultural norms become more expansive? With some frequency, writers 'discover' the Green Book, a guidebook published in the middle third of the twentieth century that advised AfricanAmerican motorists on where to find lodgings where they would be accepted and safe. Are there similar guides for transgender people, international travelers, and others who worry about acceptance and personal safety? Have hotels adjusted their physical space and practices to these populations as well as to an aging population with disposable income and a desire to continue traveling? Are there physical or management structures that encode implicit biases and how might these be different in different regions of the United States and around the world? Pursuing the answers to these and other questions will expand our knowledge about the intersection of the material world with the social and cultural world in which it exists and will bring important insights to the significance of the hotel within the study of hospitality and tourism.

Molly W. Berger is associate dean of the College of Arts and Sciences and instructor of history at Case Western Reserve University in Cleveland, Ohio. Her book, Hotel Dreams; Luxury, Technology, and Urban Ambition in America, 1829-1929 (Johns Hopkins University Press, 2011; pb ed. 2016) won the Society for the History of Technology's prestigious Sally Hacker Prize in 2012, awarded to honor exceptional scholarship that reaches beyond the academy toward a broad audience. Berger is the editor of The American Hotel (2005), an award-winning volume in The Journal of Decorative and Propaganda Arts series.

\section{Professor Kevin James responds:}

The allure of the 'grand narrative' onto which the history of the hotel was grafted was almost as alluring as the luxe amenities of the grand hotel itself. But, as the authors here have stressed, there is no one narrative of hotel history anymore than there is one hotel 'type'. The designation has variously described every form of commercial hostelry from modest, sometimes run-down, accommodation, to the rural inn to the grand hotel. If nomenclature admits of much slipperiness, efforts to grasp the hotel functions and form in either national or transnational contexts reveal that while political and legal contexts often anchor analyses of the hotel within particular jurisdictions, there were many other characteristics, from the cultures of sociability that they engendered to the business structures that many of them assumed, that a transnational lens illuminates. As A.K. Sandoval-Strausz notes, the legal frameworks within which the hotel's operation was regulated diverged in America and Britain, 
they were still united under a common law that, to many Britons, protected them from the overweening state. And as he and Molly Berger detect distinctions in the American hotel, Daniel Maudlin finds evidence of features that unite the hotel and inn culture of the 'British Atlantic world'. Unsurprisingly perhaps, the spatial and chronological framings of hotel history may tend to privilege and nourish specific lines of inquiry, including the 'birth' and dissemination of a particular institutional type, the relationship between the hotel and cultures of sociability, and their emplacement within political [word missing here!]

Both Cédric Humair and Maurizio Pellegi note that the field of hotel history is in comparative infancy. Humair argues convincingly that, in continental Europe, the study of the hotel was the province of the scholar of architecture until others, including economic and social historians such as Humair himself, positioned the hotel within new research agendas embracing tourism systems, the organisation of capital, management and labour in tourism development, and the relationships between hotels and paths to industrialisation. A critical point raised by all of these authors centres on the sheer diversity of 'hotel' types. This is a point that A.K. Sandoval-Strausz has made clear in his study of America, where the moniker was adopted by everything from the modest main street hotel to the largest urban skyscrapers. Indeed, Daniel Maudlin reminds us that the category itself was unstable, and argues persuasively for seeing continuities between the 'inn' and the 'hotel' and for querying a distinction that may be much more fluid that often assumed - and perhaps partly a retrospective construction in narratives of progress that Molly Berger has studied so deftly, as well as an interwoven nostalgia that reified the inn in popular imagination and produced a strong distinction between them. He also invites a much deeper and rigorous examination of the inn as a complex social, cultural and commercial institution (indeed he encourages us to explore the inns within a hierarchy), rather than relying on sentimentalised portrayals of it for which it serves as a foil to the 'modern' hotel. This is a critical research agenda that would repay scholars who seek to pick apart not only the discourse that produced the dominant image of the 'country inn', but also to explore the ways it was commodified in the twentieth century with the rise of the 'pseudo inns' that Daniel Maudlin identifies. I don't use this phrase, reads like quote marks rather adverted comma fingers!

Advancing this agenda of 'unevenness, contingency, and contestedness' (as Andrew Sandoval-Strausz describes it), Maurizio Peleggi stresses ways in which the hotel of the métropole was no 'transplant'; though it was a principal site of technological diffusion and also a place for the reproduction of metropolitan cultural styles, they were shaped by, and a shapers of, the distinctive racial, class and gendered dynamics of the colonial environment, many of which were more shaded and grey than the 'metropolitan' and colonial 'other'. They were nodes of sociability at the local level, and nodes within wider networks of circulation - of people and capital - at the imperial level. But, as Peleggi's work suggests, the value of studying the colonial hotel extends beyond the period of formal colonialism. The hotel played a critical role in contests that surrounded colonial modernity - and their aesthetics, their practices and the furnished symbolic and material affordances in post-colonial environments for projects as diverse as the appropriation of the colonial hotel as a marker of nationhood, or as a target for physical destruction. Cédric Humair's contribution reminds us that the hotel, grand or otherwise, played a different role in local and regional economies, and that one of the critical contributions of economic and social 
historians of hotels has been to relate their functions to wider 'tourist systems' and, beyond tourism, to processes of economic evolution in which the hotel can serve as a catalyst for industrialisation. Engaging the economic history of the hotel both from the standpoint of the history of the firm, but also from a position that analyses its relationships to broader local and regional economies, allows us to develop new perspectives on its relationship to industrialisation. The narrative mode of the 'building biography' favoured by many scholars of the hotel, remains a valuable way to engage with the strategies through which institutions adapted to, and exerted influence over, their wider environments - at catalysts for wider industrialisation, for instance, or as centres for the elaboration of civic consciousness.

What is also critical to these reflections is the agency accorded to hotel space in the shaping of identities and relations of class, race, and gender. Their material affordances and symbolisms are critical to mediating those relations. 'Hotel life' concerned many early twentieth-century scholars cited by Sandoval-Strausz, for whom the hotel was a distinctive product of urban modernity. They often invoked the soaring palace/grand hotels whose swarming lobbies and cell-like rooms signalled both the intensity and the fleetingness of hotel sociality. In contrast, the scholars here have all underscored the diversity of hotel forms, the subjectivities and relations that they engender, and the systems and landscapes of which they are a part. To suggest that 'hotel life' took one immutable form, that was in turn related to inexorable external processes that were aggregated under the concept of 'modernisation', or that it was encased within a particular building type, elides the diversity of their architectural styles, urban, rural and suburban environments in which they developed; the variety of political contexts, regional, national and transnational networks which channelled travellers, capital, and hotels aesthetics; and the diverse symbolic saliences with which hotels were endowed over time.

The roundtable has offered occasion for leadings scholars of hotel history to underscore the work that has been done, and the wider agenda to which further scholarship can contribute, as we chip away at the monoliths of hotel culture and examine the capacity of hotels to shape narratives of tourism history, and also of history of colonialism, capitalism, technology, mobility and sociability on a range of scales. 